\title{
DISPLACED MARGINS AND MISPLACED EQUITY: CHALLENGES FOR SOUTH AFRICAN HIGHER EDUCATION
}

\author{
V. Pillay \\ Department of Sociology \\ University of Pretoria \\ Pretoria, South Africa \\ e-mail: venithapillay@gmail.com
}

\section{ABSTRACT}

This article makes a single point: that the goal of institutional diversity falls short of the goal of equity in higher education. Put differently, while the margins for diversity have increasingly been displaced and dislocated, equity appears to be misplaced. I contend that through significantly increased access, the South African education system has made remarkable progress in achieving racial, ethnic and gender diversity in their student populations. Despite these achievements in diversity, however, equity, measured through the graduation rates of historically disadvantaged students, trails behind diversity achievements. At the risk of taking a parochial posture, my goal is use the challenges of the mature (American) and relatively immature higher systems (South African) to point to "lessons" that may be locally valuable. I draw on selected quantitative data that illustrates the trends in diversity and equity. I use the challenges with respect to diversity and equity in the United States system as a foil against which to read the South African quantitative trends. In so doing I show that time and maturity, demonstrated through the highly reputed American system, may not fix issues of equity and that conscious and that the South African system requires active interventions to address these challenges.

Keywords: diversity, equity, gender, transformation, capabilities approach

\section{BACKGROUND}

In December 2016, the embattled outgoing President of South Africa made a last-ditch effort to retain power by announcing, at a politically tense and potentially volatile national conference, his intention to offer free higher education for first year students whose families earned below R350 000 (approximately \$30000) per annum. The announcement sought to signal his support for the student protests that have occupied the centre stage of the higher education landscape since 2015, win working class support and to throw oppositional groups into disarray. Arguably none of this materialized. What did happen though was that universities found themselves catching the political football that the president had launched and having to find ways to implement this new left-handed policy in a matter of weeks. Once again, the politicality of higher education took precedence over educational goals. From the global student protests of 
the 1960's to the recent protests at university campuses across South Africa, there is little doubt that higher education will remain, rightly so, a deeply politicized space.

The South African Higher Education Act of 1997 was driven by a strong political will to address the skewed racial landscape of South African higher education by ensuring that universities made active and conscious effort to increase the number of black, mainly African students in the system. While I unequivocally recognize the value of our nationally driven directive to foreground race to ensure inclusion of historically disadvantaged students more than twenty years down the road, it is important to look at where we have travelled to. I make a single point in this article: that the political goal of increasing access to historically disadvantaged students needs to be revised to ensure achieving equity for historically disadvantaged students. This article explores how a Capabilities Approach may turn our attention beyond the goals of racial inclusion and reach for equity goals that may arguably serve the higher education system well.

\section{INTRODUCTION}

I write this article as a South African academic living in the United States. While my engagement with the South African higher education ${ }^{1}$ system is deeply embedded in my dasein, my interaction with American higher education is largely that of an outsider. I am deeply conscious of my outsiderness in my physical home and simultaneously pained by my distance from my emotional home. I feel helpless and desperate as I watch, from a disturbing distance, the higher education system, so central to our prosperity, being brought to its knees. Given my own role as a student leader in the 1980 education boycotts that changed the course of education in the country, I am torn between my history and the future of my country. This article is an expression of the activism available to me now: that my academic work picks up and carries forward the baton for transformation.

As a South African, I position myself as an outsider looking in at the American higher education landscape and ask what lessons may be learned with respect to inclusion and equity from the United States for a developing country like South Africa? As a guest lecturer at several American universities, I have presented discussions on, inter alia, South African higher education post-apartheid. A resounding point has emerged from the almost exclusively American audiences: that more than 50 years after the civil rights movement and Brown $\mathrm{v}$. The Board of Education (1954), which made racial segregation in education illegal, inclusion and equity in higher education remain a challenge. Put differently, the American experience shows that time will not fix the problems of equity in higher education

In engagements with a mainly American audience of executive doctoral education 
students at an Ivy League institution, I noted two competing discourses among participants. The first was a visible reluctance to engage with matters of race, premised on what I understand to be the belief that race does not play a role in the life opportunities of American people. O'Neil Green and Trent $(2005,102)$ put it as follows, "in the light of ... lingering tensions between racial/ethnic diversity and democratic participation, the discourse of a diverse democracy ... is unfortunately distorted by political and social entities that wish to ignore, discount, or vilify racial/ethnic influences in American life". Denying racial inequality, or as Dowd and Bensimon (2015, x) suggest, adopting a "color blind" approach, serves in effect to obscure and simultaneously perpetuate white privilege.

The second opposing discourse was that race is often a critical factor in life opportunities and outcomes, especially for people of color. This view is volubly evidenced in the Black Lives Matter movement that began in 2013 in the aftermath of the acquittal of George Zimmerman on a charge of second-degree murder for killing a young black man - a movement which has gained momentum with the subsequent killings of black people under controversial circumstances (see http://blacklivesmatter.com/ and http://www.cnn.com/2013/07/13 /justice/zimmerman-trial/; see also O’Neil Green and Trent 2005).

I find no comfort in the fact that the mature American higher education system continues to grapple with issues of equity. It signals that time will not fix the inequities that persist in South African higher education.

\section{METHODOLOGICAL APPROACH}

Structurally this article begins with insights into the key concepts that underpin this study: inclusion, equity, and a capabilities approach. I then present a brief literature review that examines the challenges with respect to inclusion and equity in both countries. I adopt a discursive strategy that speaks to the resonances and nuances in the two systems. I do not by any measure take a comparative stance. I juxtapose incidents, stories, data and theoretical analyses from both places, in an effort to expand the frontiers of resonance and insights for higher education in both countries. In so doing I embed and integrate relevant literature from both systems into the fabric of my discussion. Where possible, I set the young South African and well-established American systems alongside each other, albeit on unequal terms. I follow this with a discussion of key defining moments in South African higher education since the advent of democracy in 1994.

I then draw on selected quantitative data that illustrates the trends in achieving inclusion, and to a limited extent, goals of equity in each country. My purpose is to present the challenges with respect to inclusion and equity in the United States system as a foil against which to read 
the South African quantitative trends. An underlying point here is that the South African higher system should recognize that the persistent challenges evident in American higher education suggest that, in this instance, time and maturity may not fix the challenges with respect to equity and that conscious and active interventions are necessary.

With respect to South Africa I show that despite significant achievements with respect to access the goal of inclusion, the low graduation rates for historically disadvantaged students, in other words the equity profile, in South Africa is disturbing. For the purposes of this article graduation rates are calculated as the number of graduates as a percentage of the number enrolled for a given year. ${ }^{1}$ This means that with a "perfect" rate of graduation the maximum that can graduate will be approximately 25 per cent given that the expected time for an undergraduate degree is four years. The definition also means that if enrolments increase dramatically, as is evident in South Africa, the graduation rate will likely be underestimated and not accurately reflect the real graduation improvements in any given year. The American higher education system generally uses the cohort approach which calculates the graduation rate as the percentage of a cohort that graduates within a defined period. Theoretically, using the American approach, graduation rates can feasibly reach 100 per cent. ${ }^{3}$ Therefore this article does not attempt to make any direct comparisons between the graduation rates across the two systems but offers some analysis of trends within each system.

Finally, I draw on a capabilities approach to provide a conceptual framework for my argument that universities in South Africa should center equity goals while maintaining a watchful eye on inclusion.

\section{CONCEPTUAL PLATFORMS}

\section{Inclusion}

While I use the term inclusion to encompass a variety of social descriptors of historically marginalized and excluded people. These will include but are not limited to race, gender, ethnicity, social class, sexual orientation and place of origin. or the purposes of this article I focus largely on matters of race and gender since these have been the core signifiers of exclusion and inclusion in the history of higher education in South Africa and, arguably, in the United States as well. ${ }^{4}$ I use the term equity to include elements of inclusion, but more significantly, to focus on issues beyond inclusion.

\section{Equity}

Equity in higher education has been understood, in part, as the growth in numbers of historically 
marginalized groups, as well as the proportional representation of such groups in the higher education population (Marginson 2011).

While I take Marginson's (2011) view that equity is about proportional representation, I suggest it is not enough. I suggest that understandings of equity must be extended to include two key elements. The first is about success for historically disadvantaged students (and staff). Put differently, even if black students entered the higher education system in South Africa in numbers that were proportional to their demographic profile, we would not achieve equity if they did not graduate from the system in a similar proportion. In other words, equity should include the opportunity to succeed and not just to enter the system.

I take the position that while inclusion has largely been about institutional access mainly with respect to race and gender measured quantitatively, equity is about the individual or groups of individuals having the opportunity to succeed in higher education. Equity focuses on what mechanisms exist to facilitate the success of those who have entered the higher education system through the recent higher education accent on inclusion. In other words, inclusion and proportional racial representation cannot be the end goal for the transformation of higher education. Equity is about going beyond inclusion and racial representation and facilitating the successful completion of a degree for historically disadvantaged students, what Marginson $(2011,23)$ refers to as a "realist approach [which] emphasizes the agency of those excluded". Lee and Manzon (2014) make the point that despite high levels of social and economic inequality in Hong King, educational equity is well served.

The second key element of equity should be about integration, about feeling at home, what Nkomo (2012) refers to as equity with respect to institutional culture. Equity is therefore also about turning around the outsider status of historically disadvantaged students and opening up spaces for them to become insiders (Lange 2013).

Nkomo (2012) also talks about epistemological equity, which examines the struggles to revise higher education curriculums, and cites the infamous "Mamdani Debate" 5 to illustrate the resistance to introducing a curriculum whose epistemological foundations are rooted in whiteness, patriarchy and "Western" thought. For the purposes of this article I focus on equity measured though the graduation rates of undergraduate students. While equity is hard to measure, despite its limitations, I use graduation rates as a proxy for equity.

\section{Capabilities approach}

I turn now to a discussion of a capabilities approach as developed by Nussbaum (2011) and Sen (2000). In the context of striving for equity, I find it instructive that a key underpinning of the capabilities approach is its recognition of human diversity and its scope to bring into relief the 
challenges faced by historically marginalized groups, for example women and people of color.

In searching beyond the limitations of an economic measure of development in a nation, Sen (2000) advanced the notion of human capabilities, which focuses on "what people are actually able to be and do, personally and in comparison to others" (cited in Walker 2006, 21). Sen argues that capabilities are the opportunities to achieve well-being, where well-being is understood to refer to the ability to do what a person values and wants to do. As he puts it, "development [both personal and national] consists of the removal of various types of unfreedoms that leave people with little choice and little opportunity of exercising their reasoned agency" (2000, xii). He goes on to say that "what people can positively achieve is influenced by economic opportunities, political liberties, social powers, and the enabling conditions of good health, basic education, and the encouragement and cultivation of initiatives" $(2000,5)$. Capabilities therefore refer to the potential and opportunities to achieve well-being.

Given that capabilities are not visible or measurable, Sen (2000) advances the idea of functionings, which refers to what a person actually does. Put another way, whether a student at university passes or not may be understood as a functioning. The ability to succeed in actually getting a place at university is also a functioning. However, entry into university is not sufficient to enhance well-being, namely, being able to achieve what a student values, for example passing an examination. The ability and opportunity to achieve such functionings and, by implication, well-being, is according to Sen, intimately linked to what he calls "freedoms". As signaled in the title of his book, Development as freedom, Sen (2000) argues that development is about expanding the freedoms that people harness to enhance their functionings. He speaks of freedom as agency and freedom as power within a capabilities framework. These freedoms suggest that "the agent must have the capacity and power to act" (Marginson 2011, 29) and "have the freedom [opportunities] to bring about the achievements one values" (Sen, as cited in Walker 2006, 34). Freedom as power may be derived from "learning, knowledge and credentialing" (Marginson 2011,30). In other words, a student who comes to university and is able to deploy freedom as agency by harnessing the appropriate capabilities and opportunities to achieve the functioning of graduating is deemed to be exercising freedom as power.

In the higher education context, the ability to convert capabilities into functions is strongly dependent on what Sen (2000) describes as conversion factors. Personal conversion factors like socio-economic status, the availability of good nutrition, the type of schooling an undergraduate student may have had, and the willingness to learn, are instrumental in converting capabilities into functionings. However, social and environmental conversion factors in a university context are also critical. For example, social conversion factors like university policies that seek to 
identify and support at-risk students, enabling and encouraging an anti-racist inclusive climate, and providing bridging programs that serve to better prepare historically disadvantaged students for university education, are likely to play an important role in whether a student is able to use agency freedom to achieve desired functionings. Environmental conversion factors like proximity to university, decent housing and safe transport are also likely to play a significant role in achieving functionings.

Unlike Sen (2000), who leaves capabilities as open ended and developing, Nussbaum (2000) develops a list of universal capabilities which will arguably "optimize" functionings or create the conditions for a "good enough" life (see Walker 2006, 110-121). I remain ambivalent about the value of a universal capabilities list. Instead, I take to heart Marginson's $(2011,23)$ "realist approach [which] emphasizes the agency of those excluded" and find value in Walker's (2006) proposition of a locally developed capabilities list for higher education. Such lists may be developed through intense and extensive debate, and discussion among defined communities, perhaps using a combination of the top-down and bottom-up approach described by Wilson-Strydom (2016). However, suggesting what may constitute such lists is outside the ambit of this article. Nevertheless, the literature review that follows may offer some insight into key concerns that arguably may form part of such lists.

\section{REVIEWING THE LITERATURE}

McLean and Walker (2012) discuss an 18-month-long study of professional capabilities for university-based education in terms of poverty reduction, using the case of a school of engineering at a South African university. They sought to explicate what educational arrangements are necessary for producing professionals and offered a professional capabilities index that is empirically grounded in evidence from a wide range of stakeholders. For example, participants spoke of the need to understand how institutional structures shape individual lives, of how pedagogy should value diversity, and how experiential learning has the potential for opening possibilities for different ways of knowing and of building institutional cultures that encourage the confidence to act for change. The authors suggest that the index is not a blueprint of capabilities, but should be constantly renewed and negotiated in order to serve as a set of goals to direct transformation.

Wilson-Strydom (2016) argues that higher education is a capability in and of itself, and is also an enabler in the realization of other capabilities. Contrary to the notion that only students who have done well are deserving of higher education, Wilson-Strydom (2016) offers a list of capabilities that seeks to enable successful transitions from school to higher education, especially, though not exclusively, for students whose school experiences and education have 
placed them at a disadvantage. In side-stepping the list of universal capabilities that Nussbaum (2011) proposes, I find reassurance in a dynamic, dialectic and institutionally based list, as well as value in the genesis of this direction as offered by McLean and Walker (2012) and WilsonStrydom (2016).

There is strong conceptual resonance between Wilson-Strydom (2016) and Kiyama, Museus, and Vega (2015), who write about what institutional transformational processes are necessary to improve the chances of Latino/a students to achieve success at historically white universities in the United States. Kiyama et al. (2015) offer a nine-point "model" that speaks to fostering a suitable cultural and learning environment necessary for the success of Latino/ $\mathrm{a}^{6}$ students. Wilson-Strydom (2016) and Kiyama et al. (2015) note the importance of supportive institutional cultures that recognize and respect the cultural communities of historically marginalized students, the need for visionary leadership and for building curriculums and pedagogy that speak to the history and multiplicity of ways of knowing evident in the diversity of knowledge and cultural communities at modern-day universities.

Jayakumar, Vue and Allen suggest that young black students the United States "embrace college-going as an act of resistance to deficit-based narratives regarding the racial achievement gap and social reproduction" $(2013,551)$. Using Bourdieu's (1977) theory of cultural capital they write of the importance of navigational capital which refers to the ability of students of color to "navigate social institutions not created with communities of color in mind" (Yosso, cited in Jayakumar et al. 557) Taking a similar conceptual stance, Lee and Manzon (2014) use Bourdieu's notion of the logic of practice and argue that the social and cultural capital of resilience and a strong work ethic facilitates the achievement of educational equity in the Hong Kong.

In taking the discussions with respect to epistemology and historically marginalized groups further, Monzo and SooHoo $(2014,147)$, both women faculty of color at an American university, explain "we wonder whether dominant groups can ... recognize the value of our diverse ways of knowing embedded deep in our cultural repertoires and histories of exclusion?" The same authors point to the fact that, in 2011, the racial makeup of full-time faculty in the United States was 79 per cent white, with faculty of color comprising only 19 per cent (2014, 151). However, they argue that the discussion about inclusion and equity is not simply about bringing in more people of color, but about foregrounding the "ontological and epistemological exclusions" experienced by people of color $(2014,148)$. In a similar vein, Bentley-Edwards and Chapman-Hilliard's (2015) study of 242 black students at an American higher education institution suggests that building success and resilience for black students requires understanding various aspects of social competency, social responsibility and agency. 
In writing about the role of chief diversity officers at universities in the United States, Harvey $(2014,92)$ says

"[a]lthough external observers often consider colleges and universities to be very liberal social environments, change resistant behaviors and attitudes loom large within these institutions as a means of maintaining the privileges enjoyed by those individuals and groups for whom the system offers the legacy of preferential treatment. Further, the very history and evolution of higher education institutions in America plainly reveal that the academic culture has willingly embraced the exclusion of minority group members."

It has taken more than half a century for American universities to create a position such as a chief diversity officer but, as Harvey (2014) points out, diversity and inclusion without equity has little value. The claim made by Amy Gutmann, the president of the University of Pennsylvania, that the under-representation of African Americans in senior administrative roles is due to a lack of qualified individuals to fulfill these roles, has echoed hollowly through the halls of universities in both countries (Gasman, Abiola and Travers 2015). ${ }^{7}$ In a similar vein, the oft heard pipe line myth is debunked by a recent (2017) report of the American Council on Education (ACE) on the status of women in higher education, and is shown to be a mechanism for perpetuating white male dominance in higher education. The ACE report shows that women have earned more than 50 per cent of all doctoral degrees across the country since 2006.

Bozalek and Leibowitz (2013) tell several stories of exclusion. One involves a young African student, Lindi, from a rural area in South Africa. She had been the top student in her school, and was well known in her community; however, shortly after she gained admission to a historically white university, she was quickly made to feel a stranger for whom there was no care and concern. Another story recounts a Nigerian medical student who was expected by her classmates to sell drugs even while tending to patients; and yet another tells of a colored youngster who could not focus on exams as he did not have enough money to pay his fees. For these young people, marginalization, exclusion and deprivation coalesced through a multiplicity of factors, and access alone could not be translated into success. Their plight is poignantly patent in low graduation rates.

Finally, the nexus of the literature reviewed here is the about epistemological access and success. In this context, the literature points to a host of bridging programs aimed at improving epistemological access and success. For example, Bharuthram and McKenna $(2012,581)$ offer insight into the difficulties students face in the "uncharted territories of academic writing". They suggest that all university curricula should include a focus on academic writing, a skill which is indeed included in Wilson-Strydom's (2016) list of capabilities for universities in South Africa. Dowd and Bensimon's (2015) suggestions as to how American universities may work 
towards stronger equity for historically disadvantaged students also find resonance in WilsonStrydom's (2016) capabilities list. A common refrain among the articles reviewed is that historically marginalized and disadvantaged, who are also frequently first-generation university students, have particular challenges with respect to epistemological access and success.

I turn now to an overview of key political moments that have significantly shifted the higher education landscape.

\section{THE SOUTH AFRICAN HIGHER EDUCATION SYSTEM}

The evolution from apartheid to democracy in South Africa is recorded as a proud moment in world history. For higher education in South Africa, this meant finding ways to include the millions of young people previously excluded from higher education, or relegated to Bantu ${ }^{8}$ education. But access was only one element of a complex problem, compounded by decades of marginalization and inferior education.

\section{Defining moments 1994-2016}

The last twenty years have demonstrated extraordinary changes in higher education in South Africa. The Higher Education Act 101 of 1997 (Republic of South Africa 1997) created a unified system that brought 19 racially and ethnically divided education departments under one national ministry (Jansen 2002). This was a watershed moment and accepted as a necessary step for the unification of the higher education system.

Between 2000 and 2002, in keeping with the mandate set by the Higher Education Act 101 of 1997 (Republic of South Africa 1997), a series of institutional mergers took place (Jansen 2002). This process, although not without contestation, rationalized the number of higher education institutions from 36 to 23 . Following the mergers and the non-racial unification of higher education, two unexpected events had a devastating impact on the national consciousness. One event occurred in 2008 (the Reitz incident), and the other in 2012 (the University of Johannesburg stampede), each of which is discussed below.

The Reitz incident refers to an online video in 2008 , in which four white male students at the University of the Free State hazed one male and four female, black, elderly cleaning staff, by forcing them go down on their knees and eat food in which they had apparently urinated. To add insult to injury, the video went on to win first prize at a cultural competition at the university residence. Given the immense disparities between the power of the white Afrikaans men and the African workers - in this instance, mainly women - they had little choice but to eat the food. The young men said that they were protesting the racial integration of the Reitz Residence, a university residence that had previously been exclusively white. The incident became 
infamously known as the Reitz incident ${ }^{9}$ (MacGregor 2008).

This incident sent the psyche of the nation reeling. For many, the anger towards the humiliation generated by apartheid was reawakened and the desire for retaliation was intense. The government responded quickly by setting up a Ministerial Commission on Transformation and Social Cohesion and the Elimination of Discrimination in Public Higher Education Institutions (Department of Higher Education and Training [DHET] 2008). The Commission was asked to investigate all universities to understand the extent of racism and to build a picture of how institutional transformation was, or was not, taking place (MacGregor 2008). Needless to say, the Soudien Report $(2008)^{10}$ found evidence of insidious and often difficult to prove forms of racism and gender discrimination to be pervasive at South African higher education institutions. The report also pointed to the fact that institutional transformation policies existed largely on article and very little was being done to implement transformation plans.

The second incident that shook the nation was the death of an African mother in January 2012, while waiting with her son at the gates of the University of Johannesburg from the early hours of the morning in an effort to gain university admission for him. Newspapers were filled with pictures of a large gathering of parents and students waiting to register. When the gates were eventually opened, a stampede ensued and this mother was crushed to death (Laing 2012). The incident left the country in mourning. It was evident that this mother and her son had travelled a long way, physically, emotionally and financially, to seek entry to higher education.

Finally, in 2016, South Africa saw its higher education system brought to its knees by student protests. In October 2015, fueled by the success of the \#RhodesMustFall movement in which students called for the removal of apartheid symbols from universities, ${ }^{11}$ higher education students began a series of protests calling for a freeze in fee increases (see \#FeesMustFall). The movement gained much public and government sympathy and the president responded by declaring that there would be no tuition fee increases for the 2016 academic year. ${ }^{12}$ Simultaneously the president established a Ministerial task team comprised, inter alia, of government and student representatives. The aim of the task team was to establish a broad-based consultative process and forum though which the affordability of higher education could be addressed.

In the meantime, the Minister of Higher Education announced a capped fee increase of 8 per cent ${ }^{13}$ for 2017 . The Minister also lowered the threshold for those students who qualified for financial support, thereby increasing the number of students eligible. The announcements were met with anger by student bodies across the country. The protests that ensued took the form of violent and vitriolic action which began in September 2016 and continued to the end of the academic year. Students called for free and decolonized higher education, citing the 
epistemological hegemony of white Western thought in their curricula. Public support for students in the second round of protests waned owing largely to the destruction of property and the perception of political agendas of various political parties at play in the protests. Simultaneously the government was also criticized for incidents of violent police responses to students (http://www.ibtimes.co.uk/south-africa-fees-must-fall-protests-prove-post-apartheidborn-free-generation-myth-1526059). At the end of 2016, both government and popular public sentiment recognized that higher education in South Africa was in crisis. Equity remained one of the issues at the core of the crisis. A year later, in December 2017, the then President took ownership of the deeply fraught political battles that have been fought in the higher education terrain and attempted to deploy them as a political tool that would bring him victory (see Background). The many lives lost and sacrificed, the desperation of families wanting to see their children achieve a university degree, the efforts of the higher education leaders to address the evils of apartheid, rang hollow as the president wielded higher education as his personal weapon of war.

It is in this broad context that I review the achievements and challenges for higher education and then show a capabilities approach may offer opportunity to change the equity landscape for historically disadvantaged students.

\section{ACCESS AND SUCCESS FOR UNDERGRADUATE STUDENTS}

At the inception of democracy in 1994 there were approximately 110,000 undergraduate African students in the higher education system. By 2012 this had trebled to approximately 320,000 African students. The numbers for white, Indian and colored students remained largely unchanged. See Figure 1.

In twenty years, African students became the overwhelming majority in the higher education system, thereby addressing the core concern of government, namely, to increase access for historically disadvantaged students. The rapid expansion of access to higher education can be attributed to the conscious implementation of an affirmative action policy propelled by government, aimed at increasing access for black and female students to institutions from which they had previously been excluded. In the South African education system, equity with respect to increased access of historically disadvantaged African students has improved from 40 per cent in 1993 to a little over 80 per cent in 2014 (Council on Higher Education [CHE] 2016, 4). Equity with respect to proportional representation was far from ideal with only 16 per cent of African students participating in the system compared to 55 per cent of white students in 2012. In 2014, this figure changed to 15 per cent and 54 per cent respectively, demonstrating no significant change over the two-year period (CHE 2016). 


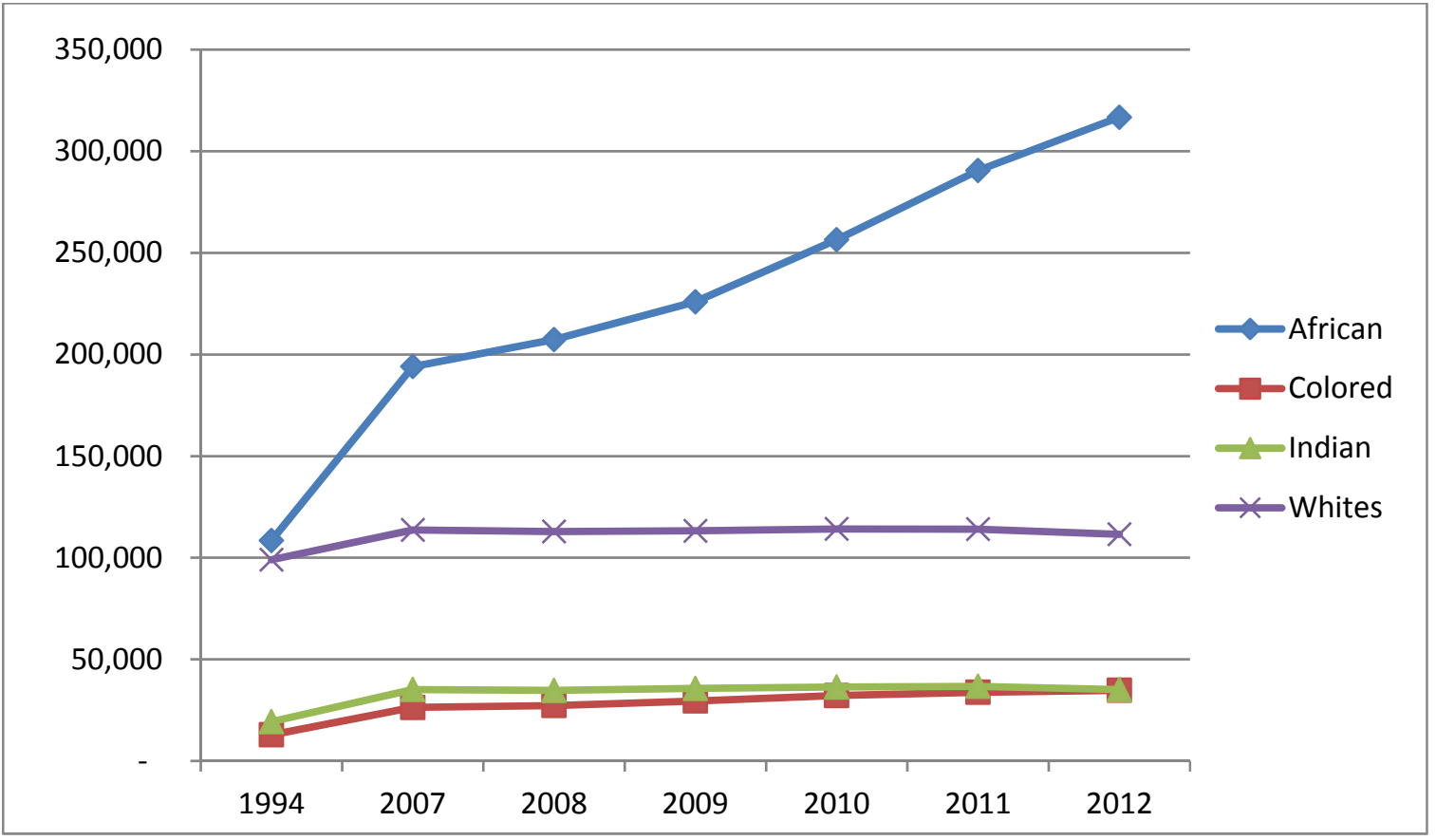

Figure 1: Undergraduate enrolments according to race, 1994 to 2012

Source: DHET (2014), Higher Education Management Information Systems (HEMIS)

In the United States the percentage of white students who enrolled at university in 1989 and 2009 shifted from 31.8 per cent to 45.7 per cent, for African Americans from 23.5 per cent to 35.3 per cent and for Hispanics from 16.1 per cent to 29.1 per cent (Kim 2011). However, it should be noted that in 2011 students of color constituted 37 per cent of the student population at two-year institutions and only 27 per cent of students at four-year institutions (bachelor degree awarding institutions) (Kim 2011,3).

Equity in the form of proportional representation with respect to gender demonstrated a positive outlook in South Africa. Female students shifted from the margins to assume a more assertive place in the system. Figure 2 shows that in 1994 female students in all disciplines were marginally more in number than male students, but by 2013 their numbers were approximately 20 per cent more than male students. Given that there was no significant difference between the number of females and males in the 20-24 years age cohort in $2011,{ }^{14}$ equity in the form of proportional gender representation is skewed in favor of females in the higher education system in South Africa (Statistics South Africa: Census in Brief 2011).

In 2014, females comprised approximately 58 per cent of all students in the South African higher education system, representing 21 per cent of the total national population, and males comprised approximately 42 per cent of all students, representing 15 per cent of the total national population (CHE 2016). Otherwise stated, the percentage of the population with respect to males in the higher education system remained unchanged (15\%) between 2009 and 
2014. The same data for women shifted from 19 per cent to 21 per cent (CHE 2016, 5).

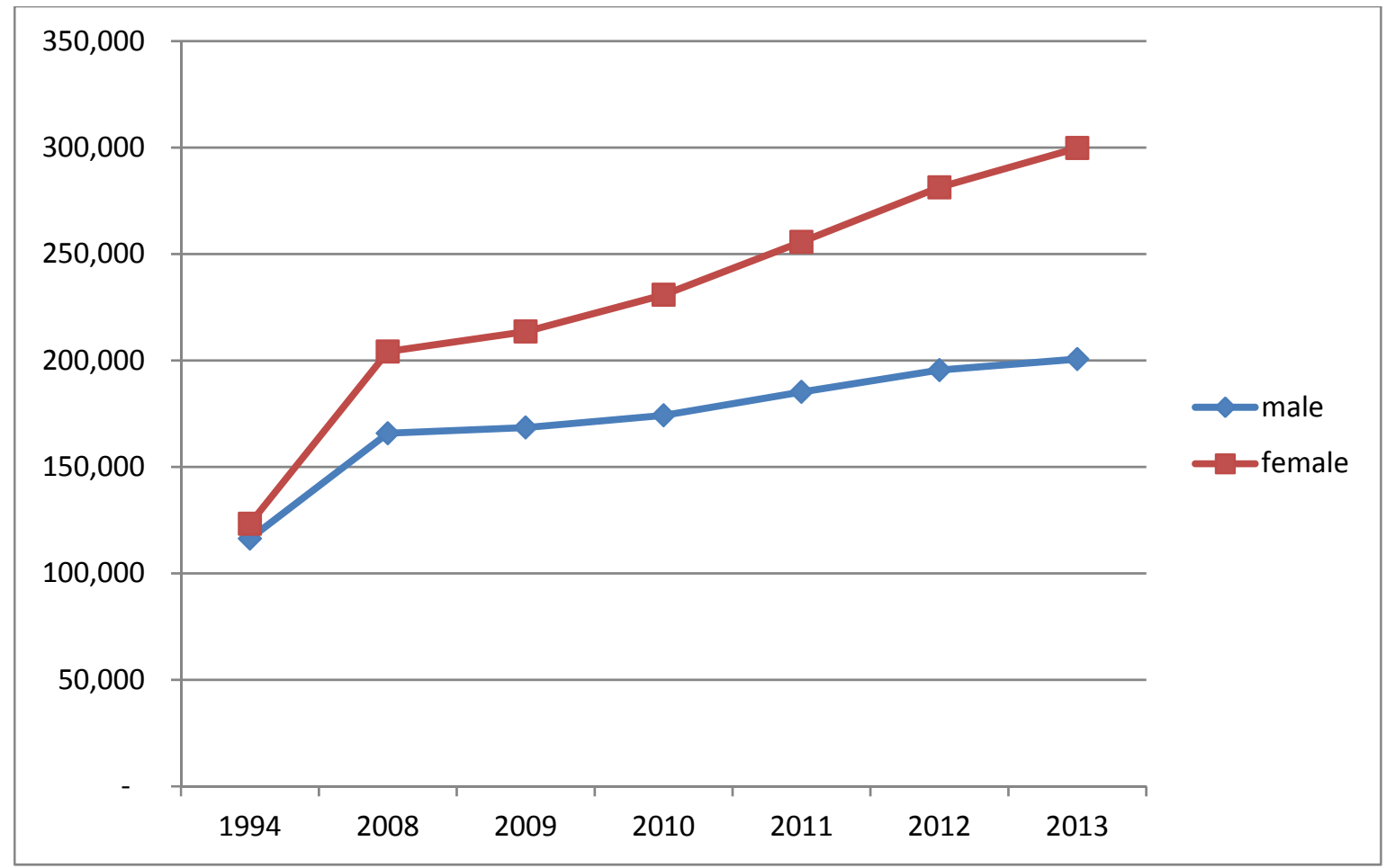

Figure 2: Undergraduate enrolments according to gender, 1994 to 2013 Source: DHET (2014), HEMIS

The number of female students of all races had almost tripled from 1994 and their graduation rate for undergraduate students over this period improved by almost 1 per cent. See Figure 3 .

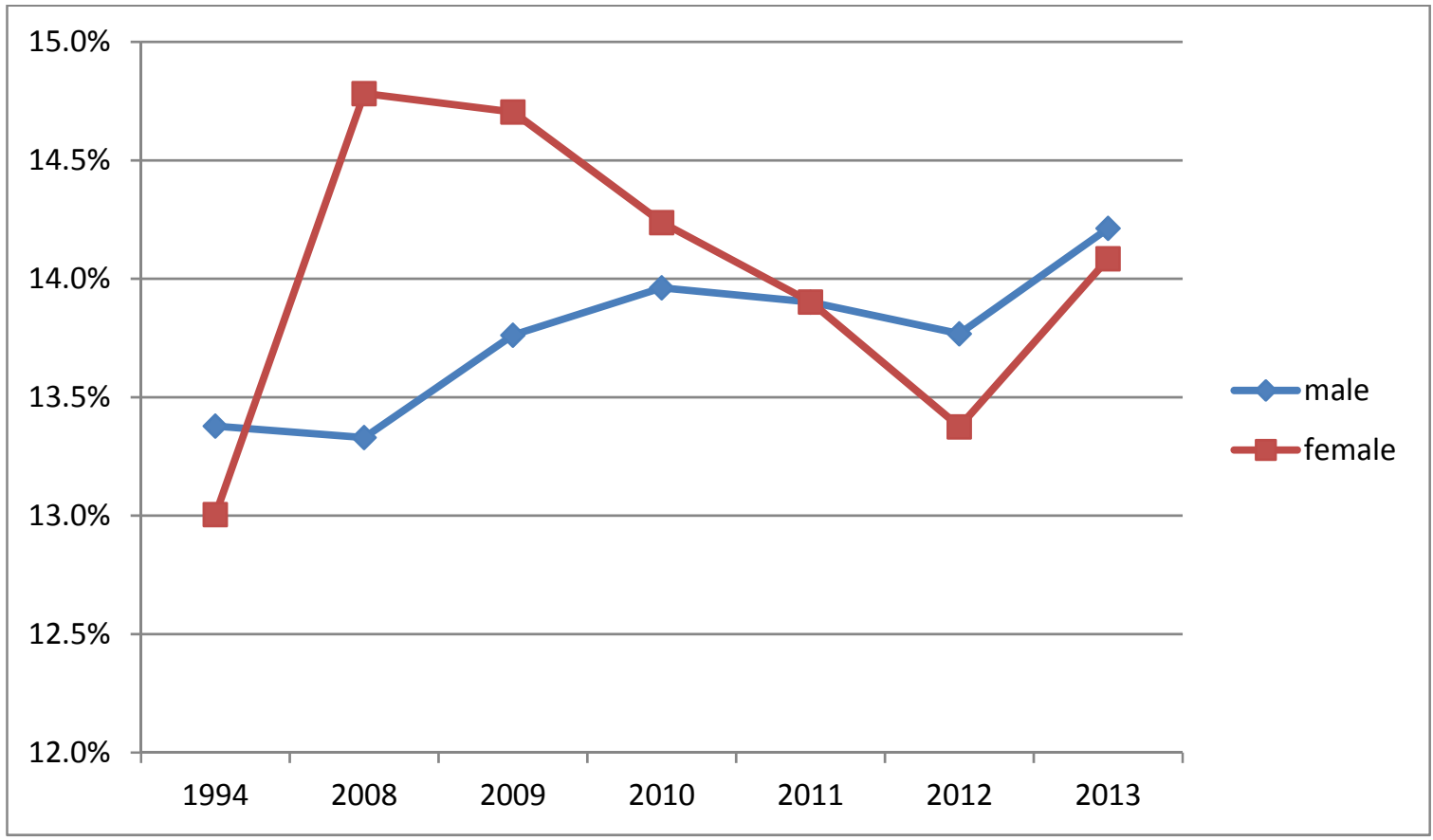

Figure 3: Undergraduate graduation rates according to gender, 1994 to 2013 Source: DHET (2014), HEMIS (http://chet.org.za/data/sahe-open-data) 
Equity as measured in the improvement of graduation rates for males and females shows a slight skewing in favor of females. As Figure 3 shows, between 1994 and 2013 graduation rates for undergraduate students for both males and females had improved with females showing a marginally better improvement. It is therefore arguable that African and female students displaced the numeric margins of the system, and became over time the largest number of higher education students in the system.

A similar gendered trend is evident in the United States. In 2009 the percentage of young adults (25-29 years) holding a bachelor's degree for African American males was 13.9 per cent (up from 12.0\% in 1989) and 21.9 per cent females (up from 13.3\% in 1989). Hispanic female graduates increased from 10.6 per cent to 15.6 per cent during the same period. The figure for Hispanic males remained unchanged at 9.6 per cent. In sum, African American and Hispanic females showed a significant improvement in the number of graduates relative to their male counterparts (Kim 2011, 6). A 2017 report of the American Council on Education shows that more women than men have earned Bachelor's degrees at American universities since 1982.

However, despite the improvement in the gender profile of graduates in South Africa, African students continued to occupy the margins of success. Figure 4 illustrates the graduation rates for students in the system over the period 1994 to 2013.

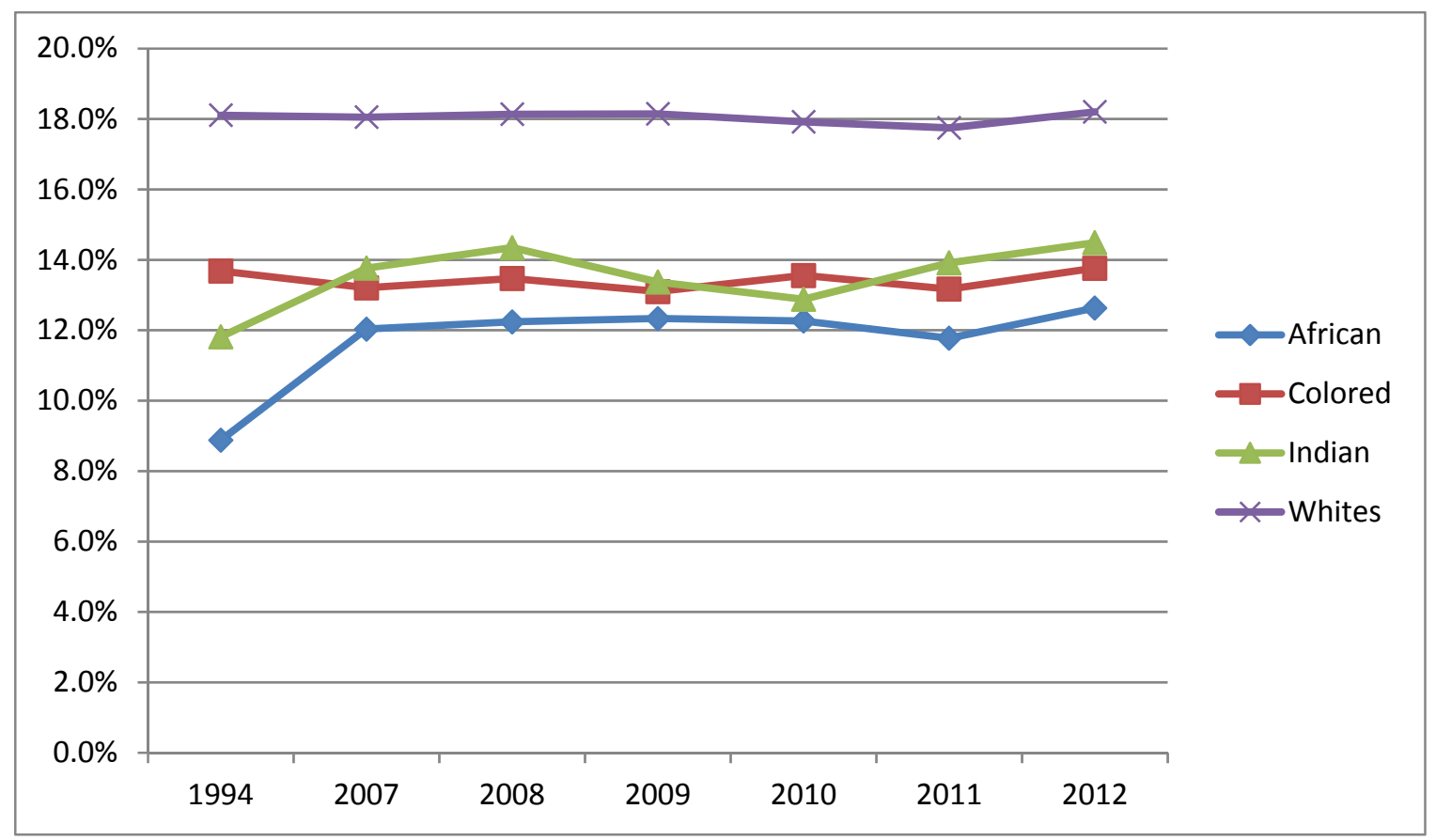

Figure 4: Undergraduate graduation rates according to race, 1994 to 2012 Source: DHET (2014), HEMIS

The graduation rate for undergraduate African students moved from approximately 9 per cent in 1994 to 12 per cent in 2012, which is the largest rate of increase across all race groups. Given 
the dramatically increased enrolments of African students their actual graduation rate is higher than 12 per cent. Although there has been a notable improvement in the graduation rate of African students, with respect to equity of outcomes, they still trail behind all other races, especially those for white students.

This trend is also evident in the cohort study for all students conducted by the CHE which shows that in 2014, 51 per cent of African students and 61 per cent of white students who enrolled in 2009 had graduated with an undergraduate degree (CHE 2016). See Figure 5.

The racially skewed graduation patterns above affirm Soudien's (2013) point that only 5 per cent of African students who entered Grade 1 are likely to obtain a degree, whereas the corresponding figure for white students is 60 per cent. In January 2017, at a high-profile meeting of the Ministerial task team established to make recommendations with respect to the "fees must fall" campaign led by students, the Statistician General of South Africa said that for every six white students who graduate, only one African student completes a degree (http://www.iol.co.za/capetimes/news/unblock-universities-urges-statistician-general2097190).

At stake for South African higher education today is how to increase equity of outcomes for African students while retaining equity of access and improving proportional equity. The capabilities of this vast majority of young people appear to be insufficiently harnessed, and they have little or no opportunity to achieve freedom as power.

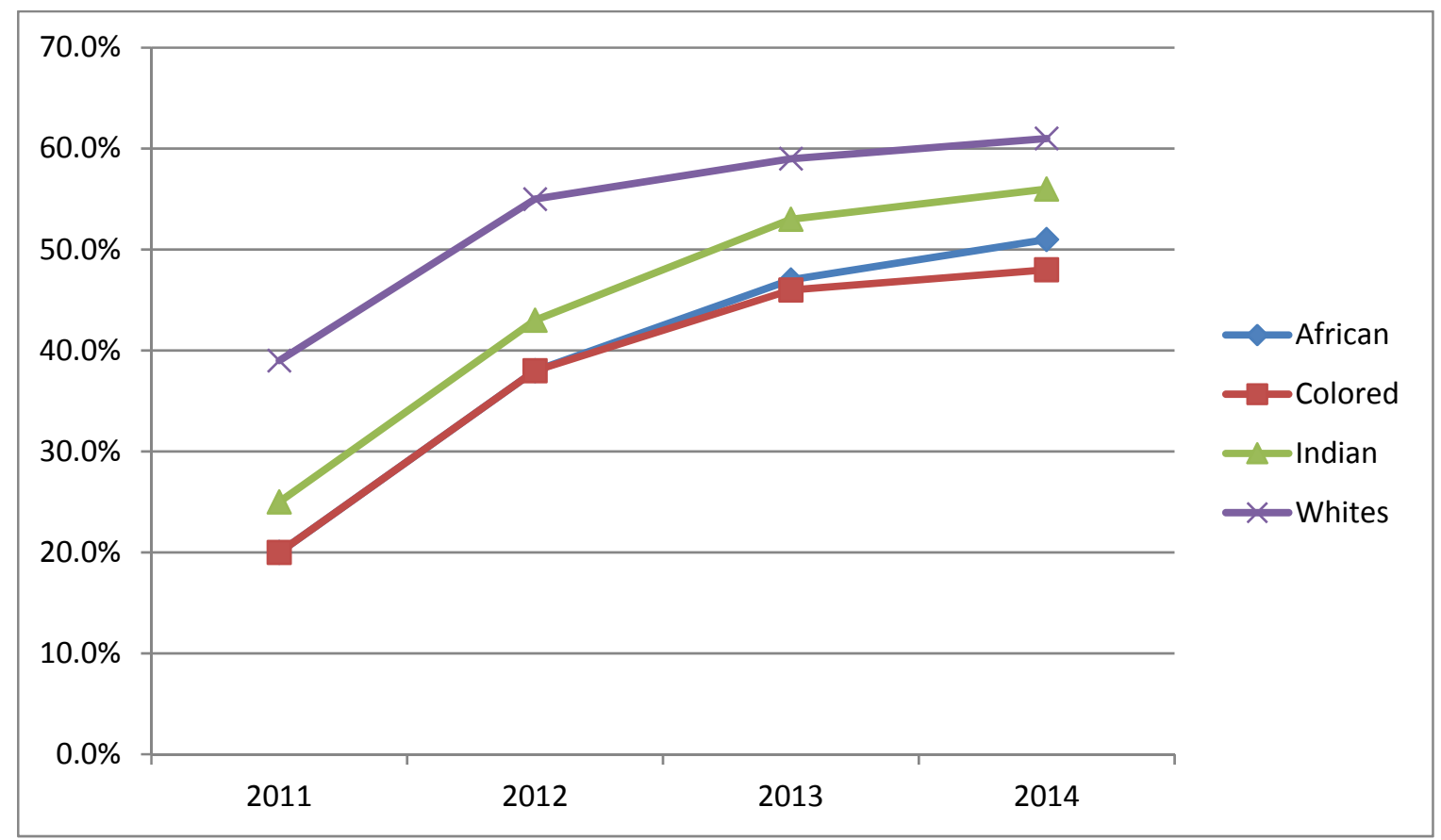

Figure 5: Cohort study (3-year degree with first year enrollment in 2009, excluding UNISA): accumulative throughput rates according to race, 2011 to 2014 (CHE 2016) 
Statistical data for the United States also reveals racial patterns of success. Flores (2014) shows that while 61 per cent of incoming white students are likely to leave with a degree after five years, only 46 per cent of black and 49 per cent of Latino students are likely to achieve the same success (Flores 2014).

Bentley-Edwards and Chapman-Hilliard $(2015,45)$ make the point that black students who attend predominantly white institutions have "attrition rates that are more than one and a half times greater than their White counterparts. Incomplete degrees, in addition to debt incurred, means that black and Latino students often do not have the opportunity for higher earnings, a potential reward for a college degree." According to Le, Mariano and Faxon-Mills (2015), in " $2013,20 \%$ of African-Americans and 16\% of Hispanics between the ages of 25 and 29 had completed a bachelor's degree, compared to 40\% of Whites" (http://link.springer.com/ article/10.1007\%2Fs11162-015-9385-8\#/page-1). It is this low graduation rate of historically disadvantaged students which is at the nexus of inequity in both systems.

\section{GOING FORWARD}

The literature review, the background profile and the data presented here makes one unequivocal and well-known point: that historically disadvantaged students, usually African and black, are at greatest risk of not succeeding at university. The article also acknowledges the numerous and varied bridging programmes aimed at facilitating success. The impact of these are not known.

In exploring how a capabilities approach may be used to facilitate the success of historically disadvantaged students, I take to heart an observation made in the 2017 American College President Study: that institutional research is critical if the profile of student success is to change. I suggest that identifying and understanding the challenges of all first-generation students at South African universities will enable an intersection of race, class and gender as potential markers of disadvantage. The students that will enter the higher education system though the president's announcement at end 2017 will in all likelihood be first generation university students. It is feasible that a significant percentage of African students who entered the system after 1994 were also first-generation students. Researching the social, environmental, personal and conversion factors that this group has and needs, developing policies and support structures that speak to such, identifying pathways to enhance the functionings of this group, carries the potential for improving the equity profile in South African higher education. I heed Lange's (2013) and Nkomo's (2012) observation that it is critical to change the outsider status of historically disadvantaged students to one where feelings of belonging may become visible. In so doing we may find ways to value what first generation 
students know and can do, a key recognition of a capabilities approach. Such an approach will give credibility to the existing personal conversion factors while simultaneously seeking pathways to extend these. I heed Marginson's words that a "realist approach that emphasizes the agency of those excluded" $(2013,23)$ is critical if first generation students are to feel included, recognize and extend the conversion factors available to them and identify ways in which their functionings may be extended. Such an approach would require universities to thoroughly research this group of students and to work closely with them from the moment they enter the system.

While I do not propose a capabilities approach as a "solution" to the elusiveness of equity, I suggest that one value of a capabilities approach lies in its focus on debate and discussion using both a bottom-up and a top-down approach. This combination of approaches could potentially speak to the multiplicity of cultures and epistemologies that inhabit the hallways of universities. In addition, Sen's (2000) focus on the importance of personal, institutional and social conversion factors as enablers for success and enhancing a sense of belonging are echoed by Jayakumar et al.'s (2013) notion of community cultural wealth. In using a capabilities approach, a potential point of departure for South African, is to ask: How do we create the possibilities (capabilities) for historically disadvantaged youth to enter (access) the higher education system, negotiate barriers (agency freedom) and succeed (freedom as power; functionings) in ways that facilitate a sense of belonging? Further, how can we ensure that their experience and worldviews are valued and they feel supported by peers, academics and administrative staff (thus enhancing personal, environmental and social conversion factors)?

\section{CONCLUSION}

The mother who was trampled to death has become symbolic of a community at risk. The African student, who is often a first-generation university student, who comes from a village and who has had limited interaction with technology, often lacks the academic and cultural capital which enables success at a higher education institution. The same may be said of American first-generation students of color who often lack the financial resources or the cultural capital to survive in institutions that are epistemologically, culturally and socially predominantly white and middle class (Jayakumar et al. 2013).

In this article, I have sought to show that inclusion without equity in higher education has limited value. That equity remains a local concern despite the cerebral and institutional sophistication and maturity of American higher education arguably signals a global lesson: that time will not fix the problems with respect to equity for historically disadvantaged students. 


\section{NOTES}

1. I use the term "higher education" to refer to research universities and exclude community colleges in the United States and further education colleges in South Africa.

2. I recognise the limitations of this definition in that the students who graduate in any given year are likely to have enrolled at least four years previously. However, I used the data in the form that it was most accessible in the Higher Education Management System in South Africa.

3. In 2016 the Council for Higher Education in South Africa began to make available graduation data using a cohort approach. This data is limited and does not show a historical trajectory. I use this limited data (Figure 5) where relevant.

4. See Brown v. The Board of Education (1954), which made racially segregated schooling illegal in 1954, just over 60 years ago.

5. In 1998, Professor Mamdani at the University of Cape Town attempted to "Africanize" and decolonize the African history curriculum. His efforts were met with much resistance from university authorities, leading to his eventual resignation. The echoes of this drive for, inter alia, epistemological equity reverberate through South Africa as I write and witness the nationwide student protests for free and, in their rhetoric, "decolonized" higher education.

6. Some authors use "Hispanic" and others use "Latino/a" to describe a largely, though not exclusively, Spanish-speaking, immigrant population. I have retained the term used by each author.

7. See also Gasman's discussion on why universities don't hire people of color summarized as "We don't want them". https://www.washingtonpost.com/news/grade-point/wp/2016/09/26/an-ivyleague-professor-on-why-colleges-dont-hire-more-faculty-of-color-we-dont-want-them/

8. An inferior form of education designed by the apartheid government for African students.

9. The Reitz incident led to the formation of the Institute for Reconciliation and Social Justice at the University of the Free State which is symbolically housed in the same building that was formerly the student residence.

10. The report of the Commission became known as the Soudien Report, named after Professor Soudien who led the Commission.

11. Students also called on universities to stop the outsourcing of cleaning services and to take responsibility to pay cleaners better salaries. In the main universities agreed to do so and began a process to this end.

12. It should be noted that unlike many other countries the South African academic year starts in January and ends in December.

13. Universities could decide the percentage of fee increases provided it did not exceed 8 per cent.

14. While this age cohort may not accurately reflect the age group of most undergraduate students, it is the cohort described in the South Africa census report that is closest to the age of undergraduate students. There were 14,750 more males in the country in this age cohort in 2011.

\section{REFERENCES}

Bentley-Edwards, K. L. and C. Chapman-Hilliard. 2015. Doing race in different places: Black racial cohesion on black and white college campuses. Journal of Diversity in Higher Education 8(1): $43-60$.

Bharuthram, S. and S. McKenna. 2012. Students' navigation of the uncharted territories of academic writing. Africa Education Review 9(3): 581-594.

Bourdieu, P. 1977. Reproduction in education, society and culture. Beverly Hills, CA: Sage.

Bozalek, V. and B. Leibowitz. 2013. An evaluative framework for a socially just institution. In Higher education for the public good: Views from the south, ed. B. Leibowitz, 59-72. London: Trentham Books. 
Brown v. The Board of Education. 1954. http://www.ourdocuments.gov/doc.php?flash=true\&doc=87

CHE see Council on Higher Education.

Council on Higher Education. 2016. VitalStats 2014: Public Higher Education. Pretoria: Council on Higher Education.

Department of Higher Education and Training. 2008. Report of the ministerial committee on transformation and social cohesion and the elimination of discrimination in public higher education institutions. https://www.ukzn.ac.za/wp-content/.../ReportHEandTransformation.pdf

Department of Higher Education and Training. 2014. Higher Education Management Information Systems (HEMIS). http://chet.org.za/data/sahe-open-data

DHET see Department of Higher Education and Training.

Dowd, A. C. and E. A. Bensimon. 2015. Engaging the "race question": Accountability and equity in U.S. higher education. New York: Teachers College Press.

Flores. A. 2014. https://www.americanprogress.org/issues/higher-education/report/2014/09/09/96689/ how-public-universities-can-promote-access-and-success-for-all-students

Gasman, M., U. Abiola and C. Travers. 2015. Diversity and senior leadership at elite institutions of higher education. Journal of Diversity in Higher Education 8(1): 1-14.

Harvey, W. B. 2014. Chief diversity officers and the wonderful world of academe. Journal of Diversity in Higher Education 7(2): 92-100.

Jansen, J. (Ed.). 2002. Mergers in higher education: Lessons learned in transitional contexts, 17-53. Pretoria: University of South Africa Press.

Jayakumar, U. M., R. Vue and W. Allen. 2013. Pathways to college for young black scholars: A community cultural wealth perspective. Harvard Educational Review 83(4): 551-579.

Kim, Y. M. 2011. Minorities in higher education: Twenty-fourth status report, 2011 supplement. Washington, DC: American Council of Education.

Kiyama, J. M., S. D. Museus and B. E. Vega. 2015. Cultivating campus environments to maximize success among Latino and Latina college students. New Directions for Higher Education 172: 2938 .

Laing, A. 2012. Mother killed in University of Johannesburg stampede. http://www.telegraph.co.uk/ news/worldnews/africaandindianocean/southafrica/9005213/Mother-killed-in-University -of-Johannesburg-stampede.html

Lange, L. 2013. The public purpose of the university: A historical view, 1995-2010. In Higher education for the public good: Views from the south, ed. B. Leibowitz, 45-58. London: Trentham Books.

Le, V-N., L. T. Mariano and S. Faxon-Mills. 2015. Can college outreach programs improve college readiness? The case of the college bound, St Louis program. Res High Educ. 57: 261. doi:10.1007/s11162-015-9385-8doi:10.1007/s11162-015-9385-8

Lee, W. O. and M. Manzon. 2014. The issue of equity and quality of education in Hong Kong. Higher Education 23(4): 823-833.

MacGregor, K. 2008. South Africa: State, universities probe racism. University World News. http://www.universityworldnews.com/article.php?story=20080410143830706

Marginson, S. 2011. Equity, status and freedom: A note on higher education. Cambridge Journal of Education 41(1): 23-36.

McLean, M. and M. Walker. 2012. The possibilities for university-based public-good professional education: A case study from South Africa based on the "capability approach". Studies in Higher Education 37(5): 585-601.

Monzo, L. D. and S. SooHoo. 2014. Translating the academy: Earning the racialized languages of the academy. Journal of Diversity in Higher Education 7(3): 147-165.

Nkomo, M. 2012. The quest for equity in higher education across racial, ethnic and gender groups. In 
Lessons in educational equality: Successful approaches to intractable problems around the world, ed. J. Heymann and A. Cassola, 23-53. Oxford: Oxford University Press.

Nussbaum, M. 2000. Women and human development: The capabilities approach. Cambridge; Cambridge University Press.

Nussbaum, M. 2010. Not for profit: Why democracy needs the humanities. Princeton, NJ: Princeton University Press.

Nussbaum, M. 2011. Creating capabilities: The human development approach. Cambridge, MA: Harvard University Press.

O'Neil Green, D. and W. T. Trent. 2005. The public good in a racially diverse democracy. In Higher education for the public good: Emerging voices from a national movement, ed. A. J. Kezar, T. C. Chambers, J. C. Burkhardt and Associates, 102-134. San Francisco, CA: Jossey-Bass.

Republic of South Africa. 1997. The Higher Education Act 101 of 1997. Pretoria: Government Printer.

Sen, A. 2000. Development as freedom. New York: Anchor Books.

Soudien Report. 2008. Department of Higher Education and Training (DHET).

Soudien, C. 2013. The public purposes of the university: A historical view, 1995-2010. In Higher education for the public good: Views from the south, ed. B. Leibowitz, 31-44. London: Trentham Books.

Statistic South Africa. 2011. Census in brief. www.statssa.gov.za/census/census_2011/census.../ Census 2011_Census in brief.pdf

Walker, M. 2006. Higher education pedagogies: A capabilities approach. Maidenhead: Open University Press.

Wilson-Strydom, M. 2016. A capabilities list for equitable transitions to university: A top-down and bottom-up approach. Journal of Human Development and Capabilities 17(2): 145-160.

Yosso, T. J. 2005. Whose culture has capital? A critical race theory discussion of community cultural wealth. Race Ethnicity and Education 8(1): 69-91. 